\title{
Ileum duplex: egy ritka elváltozás okozta differenciáldiagnosztikai kihívás
}

\author{
Simon Balázs dr. ${ }^{1}$ - Berki István dr. ${ }^{1}$ - Szabó Huba Zoltán dr. ${ }^{2}$ \\ Virág Zsolt dr. ${ }^{3}$ - Lukovich Péter dr. ${ }^{1}$
}

Szent János Kórház, ${ }^{1}$ Sebészeti Osztály, ${ }^{2}$ Patológiai Osztály, Budapest

${ }^{3}$ Mária Medical, Gasztroenterológia, Budapest

\begin{abstract}
A gastrointestinalis traktus duplikációi ritka, congenitalis elváltozások. 80\%-ban 2 éves kor előtt diagnosztizálják őket. A szájüregtől az anusig bármelyik szakaszon elófordulhatnak, de a leggyakrabban az ileum duplikációjával találkozhatunk. Klinikai megjelenésük nem specifikus és rendkívül sokféle lehet, megnehezítve a diagnózis felállítását. Éppen ezért számtalan képalkotó vizsgálat elvégzése ellenére is csupán mútéti, majd patológiai lelet tudja megerősíteni a diagnózist. A 23 éves nőbeteg hasi panaszai miatti kivizsgáláskor bizonytalan kismedencei képletet találtak, amelynek pontos eredete az elkövetkező 6 év során történt számtalan hüvelyi, hasi ultrahang (UH)-, hasi CT- és MR-vizsgálat, kolonoszkópia, laparoszkópia, sebészeti, nőgyógyászati és gasztroenterológiai vizsgálat során sem volt tisztázható: ovarialis cysta, vékonybéltágulat és Crohn-betegség gyanúja merült fel. Az utóbbi miatt megfelelő gyógyszeres kezelésben is részesült, melyre panaszai átmenetileg javultak. A hasi fájdalom, láz miatt készült UH intramuralis tályog lehetőségét vetette fel, ezért akutan ileocaecalis reszekció történt. A patológiai vizsgálat fedezte fel, hogy a beteg panaszainak hátterében az ileum duplikációja állt. Az ismertetett elváltozást rendkívül ritka előfordulása ellenére is érdemes számon tartani a nem tisztázott eredetű ileocaecalis hasû́ri térfoglalások differenciáldiagnosztikájában. Annak ellenére, hogy felnőtteknél szinte egyetlen leírt esetben sem jutottak diagnózishoz mútét nélkül, felhívja a figyelmet a lassan már feledésbe merülő pontos anamnézisfelvételre és a társszakmák közötti megbeszélések, konzíliumok szükségességére, fontosságára.
\end{abstract}

Orv Hetil. 2018; 159(52): 2217-2221.

Kulcsszavak: ileum duplex, Crohn-betegség, differenciáldiagnózis, sebészet, gasztroenterológia

\section{Ileal duplication: challenging differential diagnosis caused by a rare abnormality \\ Case report}

Gastrointestinal tract duplications (GSD) are rare congenital abnormalities. Eighty percent of GSDs are diagnosed before the age of two. These lesions can be seen anywhere from the oral cavity to the anus, but ileum is the most commonly affected site. Their clinical presentation is widely variable and unspecific, making the differential diagnosis really hard. Thus despite performing a long line of radiological scans, the diagnosis can be made during a surgery and by the pathologist. A 23 -year-old female patient presented at the emergency room (ER) with abdominal cramps. Examinations revealed an unidentified intraabdominal mass. This could not been identified through the next years despite having tons of examinations: intravaginal and abdominal ultrasonographies, CT and MRI scans, colonoscopies, laparoscopies, surgical, gynecological and gastroenterological visits. Amongst the diagnoses were: ovarian cyst, bowel enlargement, Crohn's disease. Due to the latter, she received therapy which temporarily eased her symptoms. But after these, because of abdominal pain, fever and an ultrasonography that showed an intramural abscess in her abdomen, she went through a surgery having an ileocecal resection. Pathological examination showed a duplication of the ileum that might have caused her symptoms all through the years. Despite facing this rare abnormality, it is important to keep this in mind in differentiating abdominal symptoms. It is true that in no case there could be a diagnosis made without surgery, it raises attention to the importance of precise medical history taking and also cooperation between specialties.

Keywords: ileal duplication, Crohn's disease, differential diagnosis, surgery, gastroenterology

Simon B, Berki I, Szabó HZ, Virág Zs, Lukovich P. [Ileal duplication: challenging differential diagnosis caused by a rare abnormality. Case report]. Orv Hetil. 2018; 159(52): 2217-2221.

(Beérkezett: 2018. július 14.; elfogadva: 2018. augusztus 16.) 


\section{Rövidítések}

CRP = C-reaktív protein; CT = (computed tomography) számítógépes tomográfia; GSD = (gastrointestinal tract duplication) gastrointestinalis traktus duplikációja; IBD = (inflammatory bowel disease) gyulladásos bélbetegség; $\mathrm{MR}=$ (magnetic resonance) mágneses rezonancia; $\mathrm{UH}=$ ultrahang; $\mathrm{WBC}=$ (white blood cell count) fehérvérsejtszám

A gastrointestinalis traktus duplikációi ritka veleszületett elváltozások, amelyek a legtöbb esetben 2 éves kor előtt felfedezésre kerülnek [1]. Csupán kis hányaduk marad rejtve a felnőttkorig. Az elmúlt közel 150 év során mindössze 15 eset került leírásra, amikor felnőtt betegben megerősítést nyert duplikált ileumszakasz megléte [2]. Az emésztőrendszer bármely szakaszán előfordulhatnak, de a leggyakrabban az ileum duplikációjával találkozhatunk. Ezek a képletek lehetnek tubularisak vagy cysticus megjelenésűek [3]. Jellemzően a bél érintett szakaszával párhuzamosan, a mesenteriumba ágyazottan helyezkednek el. Ezen tulajdonságuk miatt is nehéz - még akár mütét során is - felismerni őket. A tubularis forma mindig 2 ponton csatlakozik az eredeti lumenhez, de ezek le is záródhatnak, így egy korábban tubularis képlet válhat cysticussá, és akár tályog is kialakulhat benne.

Klinikai tünetei sokfélék lehetnek: hasi fájdalom, hányás, tapintható hasưri terime. Képalkotó vizsgálatokon utánozhat volvulust, invaginatiót, formálhat tályogot. A duplikált bélszakasz nyálkahártyájában metaplasia is megjelenhet, akár hasnyálmirigy-, akár gyomornyálkahártya formájában, így ennek malignus transzformációja miatt is fontos a sebészi eltávolítása, amennyiben mütét során felismerésre kerül.

\section{Esetismertetés}

2011 nyarán az akkor 23 éves nőbeteg jobb alhasi fájdalmakkal jelentkezett nőgyógyásznál. Anamnézisében jelentősebb megbetegedés nem szerepelt. Panaszai miatt elvégzett hasi, hüvelyi ultrahangvizsgálatok, hasi CTvizsgálat a jobb alhasban az ovariummal összefüggő vagy abból kiinduló, közel $7 \mathrm{~cm}$ legnagyobb átmérőjü cysticus képletet írt le (1. ábra).

A hüvelyi és hasi ultrahangvizsgálat is leírta, hogy az elváltozás fala perisztaltikázik (2. ábra). A laborvizsgálatok eredményeiben jelentősebb eltérés nem volt; a sebészeti konzílium 2 alkalommal is osztályos obszervációt javasolt appendicitis iránydiagnózissal. Konzervatív terápia mellett a beteg mindkét esetben panaszmentessé vált.

Az elkövetkező 6 évben végzett számtalan vizsgálat az 1. táblázatban látható. Ezek közül is kiemelendő az a 19 nőgyógyászati megjelenés, amely során 17 hüvelyi ultrahangvizsgálat készült. Ezek során a vizsgáló minden esetben megemlítette, hogy az elváltozás fala perisztaltikázik. Habár a nőgyógyászati kivizsgálások kezdődtek hamarabb, IBD gyanúja is felmerült, ezért gasztroenterológiai kivizsgálás is indult. Kolonoszkópia során a Bau-

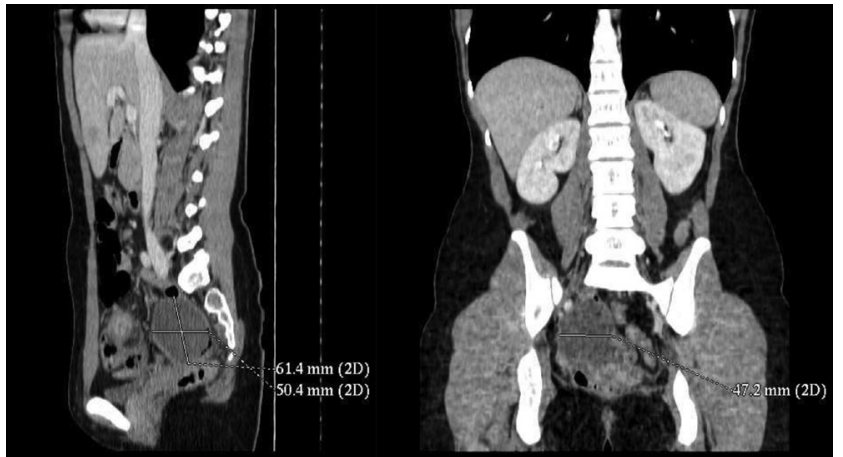

\begin{tabular}{l|l} 
1. ábra & CT által leírt cysticus képlet a kismedencében
\end{tabular}

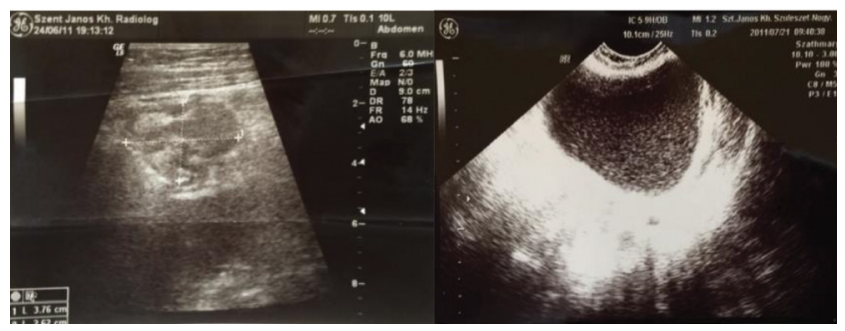

2. ábra A hasi ultrahangon látott perisztaltikázó képlet

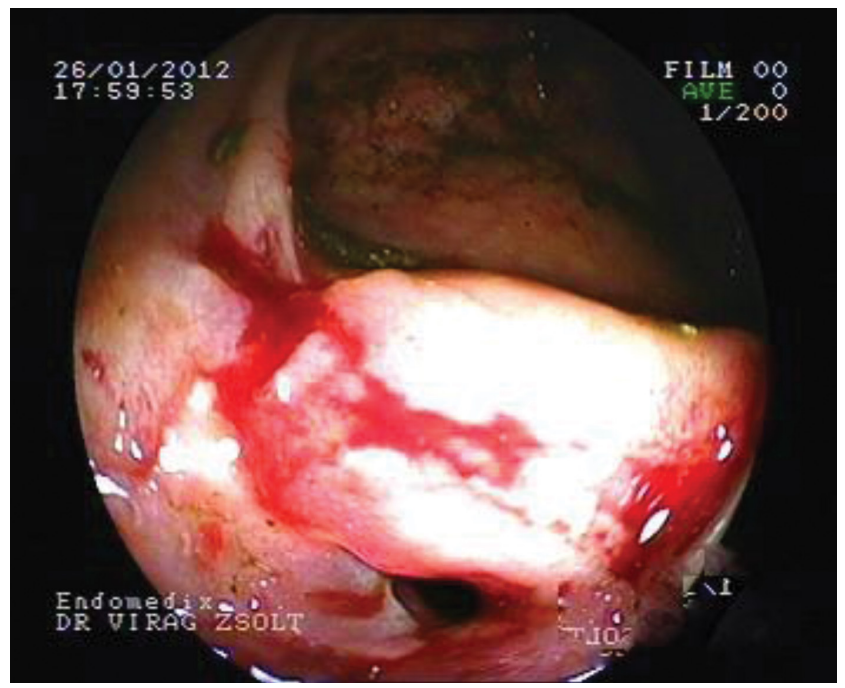

3. ábra

Az első tünetek jelentkezése után fél évvel látott kolonoszkópiás kép: a Bauchin-billentyú területének gyulladása

chin-billentyű területének gyulladását találták, az ileum intubálása sikertelen volt (3. ábra), de az ileumból vett minta gyulladást igazolt, jóllehet Crohn-betegségre jellemző granulomatosist nem láttak. A gasztroenterológus a gyulladást a klinikai és kolonoszkópiás képpel együtt értékelve Crohn-betegséget diagnosztizált. Az ennek megfelelően beállított terápia $(2 \times 2$ g Pentasa, $100 \mathrm{mg} /$ die Imuran) mellett a beteg panaszai csökkentek. Az 5 hónappal később készült kontrollkolonoszkópia (4. ábra) is a gyulladás remisszióját találta.

6 évvel a beteg első panaszainak jelentkezése után, hosszabb-rövidebb tünetmentes időszakokat követően 
1. táblázat |A 2011 és 2017 között elvégzett vizsgálatok

\begin{tabular}{|c|c|c|c|c|}
\hline Év & $\begin{array}{l}\text { Gasztroen- } \\
\text { terológia }\end{array}$ & $\begin{array}{l}\text { Nőgyó- } \\
\text { gyászat }\end{array}$ & Sebészet & $\begin{array}{l}\text { Képalkotó vizsgálat/ } \\
\text { beavatkozás }\end{array}$ \\
\hline \multirow[t]{6}{*}{2011} & & 06.07. & 06.07. & $\begin{array}{l}\text { 06. 07. Hasi UH, } \\
\text { vaginalis UH }\end{array}$ \\
\hline & \multirow[t]{5}{*}{06.24 . } & 06.24. & 06.24. & $\begin{array}{l}\text { 06. 24. Hasi UH, } \\
\text { vaginalis } \mathrm{UH} \text {, hasi CT }\end{array}$ \\
\hline & & 06.27. & & 06. 27. Vaginalis UH \\
\hline & & 07.04 . & & \\
\hline & & 07.21. & & 07. 21. Vaginalis UH \\
\hline & & 07.24 . & & $\begin{array}{l}\text { 07. 24. Diagnosztikus } \\
\text { laparoszkópia }\end{array}$ \\
\hline
\end{tabular}

2012 01. 10.

01. 26. Kolonoszkópia

02. 24. Hasi MR

04. 07.

04. 07. Vaginalis $\mathrm{UH}$

06. 14. Kolonoszkópia

06.26

08.03

08. 03. Vaginalis $\mathrm{UH}$

08. 19.

2013 01. 14.

01. 14. Vaginalis UH

02.05 .

03. 14 .

03. 14. Vaginalis $\mathrm{UH}$

06. 05. Hasi MR

2014 01. 21

$\begin{array}{ll}02.06 . & 02.06 . \text { Vaginalis } \mathrm{UH} \\ 03.24 . & 03.24 \text {. Vaginalis } \mathrm{UH} \\ 06.05 & 06.05 . \text { Vaginais } \mathrm{UH}\end{array}$

08.07.

$2015 \quad 01.27$

$\begin{array}{ll}02.25 . & 02.25 . \text { Vaginalis } \mathrm{UH} \\ 03.24 . & 03.24 . \text { Vaginalis } \mathrm{UH} \\ 04.09 . & 04.09 . \text { Vaginalis } \mathrm{UH} \\ 04.17 . & 04.17 . \text { Vaginalis } \mathrm{UH} \\ & 05.19 . \text { Kolonoszkópia }\end{array}$

06. 02 .

07.21

07. 21. Laparoszkópos cystectomia l.d.

08. 26

08. 26. Vaginalis $\mathrm{UH}$

$2016 \quad 02.16$.

$2017 \quad 08.18$

11. 09.

11. 13. 11. 13. Hasi UH, vaginalis $\mathrm{UH}$, ileocaecalis reszekció

$\mathrm{CT}=$ számítógépes tomográfia; $\mathrm{MR}=$ mágneses rezonancia; $\mathrm{UH}=$ ultrahang

hasi fájdalmai fokozódtak; a hasi ultrahangvizsgálat intramuralis tályog gyanúját vetette fel, gasztroenterológusa sebészeti osztályunkra utalta. Ekkor már laboreredmé-

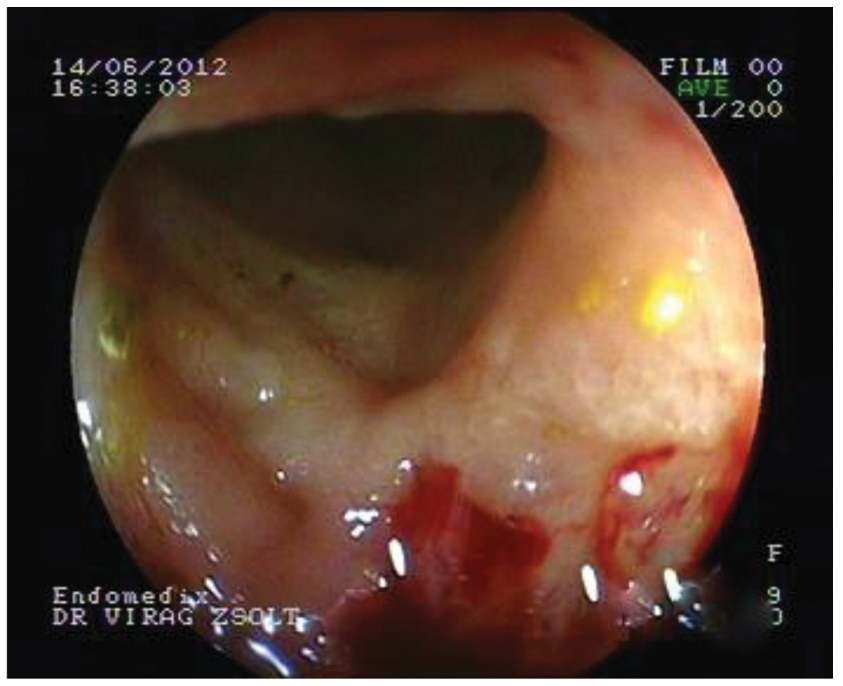
\begin{tabular}{l|l} 
4. ábra & $\begin{array}{l}\text { A Crohn-terápia beállítása után fél évvel látott kolonoszkópiás } \\
\text { kép: a gyulladás remisszióban }\end{array}$
\end{tabular}

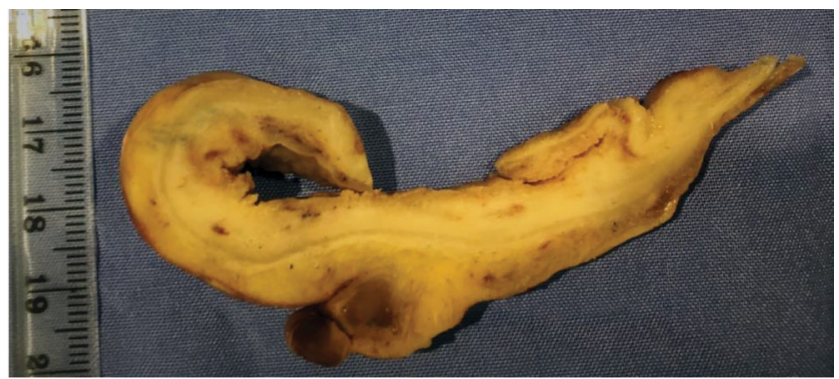

5. ábra $\mid$ Az ileum duplex. A torzulás következtében nehezebb megítélni az eredeti morfológiát. Az eredeti lumennel való közlekedése feltehetően lezárult, így alakulhatott ki a tályog

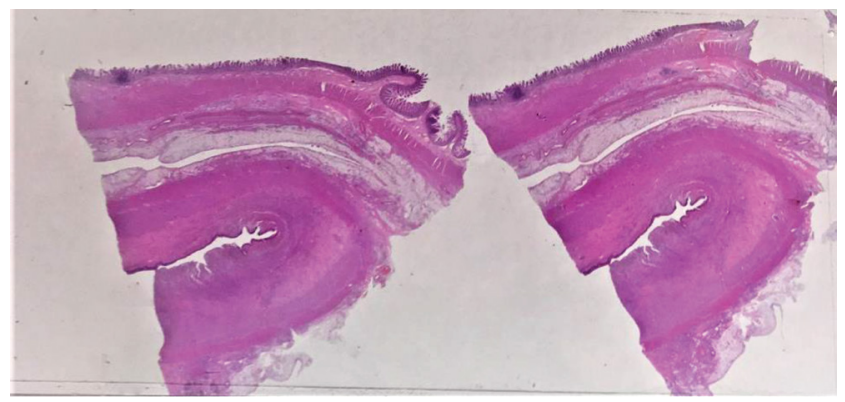

6. ábra $\quad$ A szövettani metszeten jól azonosítható a dupla lumen, benne laphám-metaplasia

nyeiben jelentősebb eltérések voltak (WBC: 18 10\%/l, CRP: $152 \mathrm{mg} / \mathrm{l}$ ). Az elvégzett kontroll hasi és hüvelyi ultrahang is szabad hasi folyadékot, valamint a korábban többször leírt jobb alhasi cysticus képlet helyén $85 \mathrm{~mm}$ legnagyobb átmérőjü, vastag falú, tályognak megfelelő képletet véleményezett. Hasi statusa romlott, ezért Crohn-betegség okozta intramuralis tályog gyanújával mútétet végeztünk, amelynek során laparotomiás feltárásból az ileocaecalis régióban lévő voluminózus, submucosus tályognak megfelelő képletet találtunk; az elvál- 
tozást ileocaecalis reszekcióval eltávolítottuk. A posztoperatív szak eseménytelen volt, a beteg a posztoperatív 5. napon panaszmentesen, rendezett passzázszsal távozott.

A műtéti specimen patológiai feldolgozásakor a terminalis ileum distalis szakaszán, a Bauchin-billentyütől 3 cm-ig követhetően egy $7 \mathrm{~cm}$ átmérőjü tömött, szürkéssárga zsírszöveti felszínnel rendelkező terimét találtak, mely az eredeti lumennel párhuzamosan - a fixálódás miatti torzulás következtében - egy összenyomott üreget formált az átmetszetben. Az üreg belső átmérője 6 $\mathrm{cm}$ volt, lumenét $4-7 \mathrm{~mm}$ vastag lemezes struktúra vette körül (5. ábra).

A kórbonctani diagnózis: ileocolectomia a terminalis ileum duplikációs cystájával, kiterjedt laphám-metaplasiával. Crohn-betegségre utaló szöveti eltérés nem volt látható. Malignitás nem volt igazolható (6. ábra).

\section{Megbeszélés}

A gastrointestinalis traktus duplikációi számtalan más állapotra jellemző, nem specifikus tünetet produkálhatnak. $\mathrm{Az}$ esetek mindössze 5-6,5\%-a marad tünetmentes, és kerül felnőttkorban felfedezésre. A diagnózis ekkor is véletlenszerü [1, 3]. Egy 2015. évi japán publikáció szerint a szigetországban addig 16 felnőtt esetében közöltek gastrointestinalis duplikációt, ezekből 4-ben az eltávolítást megelőzően diagnózishoz jutottak, leginkább a kifejezetten nagy duplikációk esetében [4].

Itthon még nem került közlésre egyetlen hasonló eset sem.

Jelen esetünket - ritkasága mellett - több szempontból tartottuk közlésre érdemesnek.

1. A klasszikus fizikális vizsgálat mellett a mai napig sem lehet elégszer hangsúlyozni a pontos anamnézisfelvétel fontosságát. Ebben az esetben természetesen nehezítette a helyzetet, hogy a beteg a CT-, hasi MR-és kolonoszkópos vizsgálatokat más-más magánellátónál csináltatta, valamint többször váltott nőgyógyászt és sebészt, valamint kórházat. Utólag sikerült csak megkapnunk az - egyébként rendkívül aprólékosan összegyưjtött - orvosi dokumentációját. A korábban végzett képi anyagok beszerzése így is komoly munkájába telt a szerzőknek. Az elózó vizsgálatok dokumentációit 6 év alatt azonban senki nem tekintette át.

2. A leletek összegyüjtése után derült ki: a transvaginalis ultrabangok minden alkalommal leirták, hogy a kismedencei képlet perisztaltikázik, ami jelentős segítséget adhatott volna a pontos diagnózis felállításához. Mivel az ileum duplex a bélfal minden rétegét tartalmazza, önálló perisztaltikával is rendelkezik. Meckel-diverticulum esetében szintén látható perisztaltika az ultrahangon, valamint nyomásra a diverticulum tartalma egyértelmüen visszapasszálható a vékonybélbe, ami cysticus duplikáció esetében már nem valósítható meg, mivel ott nincs kommunikáció a bél lumenével [5]. Bélférgesség esetében mutatkozhat élénk perisztaltika a férgekkel teli bélen, ek- kor azonban a férgek jellemzően fonalszerú megjelenése egyértelmúbbé teszi a diagnózist [6]. A petefészekcysták ultrahangos differenciálásának számtalan kritériuma van, ám a fal perisztaltikája nem jellemző rájuk. Önálló mozgást legalábbis nem tudnak végezni, csupán a vizsgálófej nyomására a bennék áramlása vagy Doppler-vizsgálattal a véráramlás látható [7].

3. Egy hónappal a panaszok kezdete után a betegnél ovariumcysta diagnózisával a nőgyógyászok diagnosztikus laparoszkópiát végeztek, amelynek során azonban a nőgyógyászati szerveket épen találták, további beavatkozásra nem került sor. Ezután kezdődött meg a gasztroenterológiai kivizsgálás és a kolonoszkópia, amelyekkel párhuzamosan további nógyógyászati kontrollokra is visszajárt a beteg; ezek során továbbra is leírásra került a perisztaltikázó képlet. A nőgyógyászokat továbbra sem hagyta nyugodni a „cysta”. A beteg eközben többször orvost váltott, és laboreredményeiben a CA-125-ös marker emelkedését is látták, végül 4 évvel az első laparoszkópia után újabb következett, amelynek során már a jobb ovarium cystectomiáját végezték, és ennek szövettana endometriosist igazolt. Cystectomiája ellenére a második nőgyógyászati laparoszkópia utáni kontrollokon továbbra is leírásra került a jobb kismedencei perisztaltikázó, cysticus képlet, holott ebben az időszakban már a beteg Crohn-betegsége is remisszióban volt. Habár nögyógyászok 2 alkalommal is végeztek laparoszkópiát az elváltozás pontositása céljából, egyik alkalommal sem gondoltak sebész bevonására - ami esetleg elósegithette volna a korábbi diagnózisfelállitást. Egyes esetismertetések említik ugyanis a laparoszkópiát a duplikált ileum diagnosztikájában, legalább ugyanennyi azonban el is veti azt [8].

4. A Crohn-betegség diagnózisa mellett szólt a két MR-vizsgálat, amelyen a terminalis ileum szúkülete látszódott. Az ultrahangvizsgálatok során látott tágult bélszakaszt praestenoticus tágulatnak tartották. A kolonoszkópia során látott gyulladt Bauchin-billentyüt vélhetőleg magának az ileum duplexnek a gyulladása okozhatta, illetve ez akadályozhatta meg az ileum intubálását. A Crohn-betegségre jellemző hullámzó, jobb alhasi panaszok, illetve az előbbi vizsgálati leletek alapján állította fel a gasztroenterológus a Crohn-betegség diagnózisát, és kezdte meg a kezelést - annak ellenére, hogy a szövettanban granulomatosus elváltozást nem láttak. Valószínúleg a gyógyszeres kezelés hatására a duplikátum gyulladása csökkent, és ez átmenetileg a panaszok mérséklődéséhez is vezethetett. A beteg az ileocaecalis reszekció után elhagyhatta a Crohn-betegség gyógyszerelését, és azóta is tünetmentes.

5. Habár egy duplikált ileumszakasz megléte ártalmatlan anatómiai variációnak tűnhet, minél előbbi felfedezése és eltávolitása igen fontos a potenciális malignizálódás veszélye miatt. Különösen igaz ez akkor, ha idősebb életkorban kerülnek felfedezésre, amikor a nyálkahártyametaplasia, akár -dysplasia is megjelenhet bennük [9, 10]. A szövettani feldolgozás során esetünkben is kiter- 
jedt laphám-metaplasiát találtak az ileum duplexben. Más leírt esetek közül az egyikben a gyomor duplikációs cystájában találtak laphám-metaplasia talaján kialakult carcinomát egy 67 éves betegben, akinek a mütét idejében már carcinosisa volt, és 6 hónappal a duplikátum reszekciója után elhunyt [11]. Ritka érdekesség, de az itt leírt esettel kapcsolatosan szükséges megemlíteni, hogy az ileocaecalis régióban megjelenő metasztázisok szintén elterelhetik a diagnózist akár a Crohn-betegség, akár más malformitás irányába, holott a háttérben malignitás húzódik. Így akár invazív lobularis emlőcarcinoma áttéte is okozhat a Crohn-betegségre vagy ileum duplexre utaló klinikai tüneteket [12].

\section{Következtetés}

$\mathrm{Az}$ ismertetett elváltozást rendkívül ritka előfordulása ellenére is érdemes számon tartani a nem tisztázott eredetû ileocaecalis hasűri térfoglalások differenciáldiagnosztikájában. Annak ellenére, hogy felnőtteknél szinte egyetlen leírt esetben sem (az enormis duplikációkat leszámítva) jutottak diagnózishoz mútét nélkül, felhívja a figyelmet a lassan már feledésbe merülő pontos anamnézisfelvételre és a társszakmák közötti megbeszélések, konzíliumok szükségességére, fontosságára.

Anyagi támogatás: A közlemény megírása anyagi támogatásban nem részesült.

Szerzői munkamegosztás: S. B.: A betegdokumentáció összegyưjjtése, rendszerezése, a kézirat megírása, kapcsolattartás a szerzőtársakkal. L. P.: A kézirat szakmai, tartalmi, stilisztikai és nyelvtani ellenőrzése. B. I.: A kézirat tartalmi ellenőrzése. Sz. H. Z.: A kézirat tartalmi ellenőrzése, a patológiai feldolgozás képeinek biztosítása. V. Zs.: A gasztroenterológiai vizsgálatok képanyagának biztosítása. A cikk végleges változatát valamennyi szerző elolvasta és jóváhagyta.

Érdekeltségek: A szerzőknek nincsenek érdekeltségeik.

\section{Irodalom}

[1] Holcomb GW 3rd, Gheissari A, O'Neill, JA Jr, et al. Surgical management of alimentary tract duplications. Ann Surg. 1989; 209: 167-174.

[2] Beltran MA. Adenocarcinoma and intestinal duplication of the ileum: report of a case highlighting the malignant potential of an uncommon condition. Clin Surg. 2018; 3: 1903.

[3] Ildstad ST, Tollerud DJ, Weiss RG, et al. Duplications of the alimentary tract. Clinical characteristics, preferred treatment and associated malformations. Ann Surg. 1988; 208: 184-189.

[4] Matsumoto Y, Tohma T, Miyauchi H, et al. A case of giant ileal duplication in an adult, successfully treated with laparoscope-assisted surgery. Surg Case Rep. 2015; 1: 10.

[5] Kotha VK, Khandelwal A, Saboo SS, et al. Radiologist's perspective for the Meckel's diverticulum and its complications. Br J Radiol. 2014; 87: 20130743.

[6] Ramareddy RS, Alladi A, Siddapa OS, et al. Surgical complications of Ascaris lumbricoides in children. J Indian Assoc Pediatr Surg. 2012; 17: 116-119.

[7] Sayasneh A, Ekechi C, Ferrara L, et al. The characteristic ultrasound features of specific types of ovarian pathology (Review). Int J Oncol. 2015; 46: 445-458.

[8] Babür T. Ileal tubular duplication; a rare cause of bowel obstruction in adults. Ulus Cerrahi Derg. 2014; 32: 78-79.

[9] Fiorani C, Scaramuzzo R, Lazzaro A, et al. Intestinal duplication in adulthood: a rare entity, difficult to diagnose. World J Gastrointest Surg. 2011; 3: 128-130.

[10] Blank G, Königsrainer A, Sipos B, et al. Adenocarcinoma arising in a cystic duplication of the small bowel: case report and review of literature. World J Surg Oncol. 2012; 10: 55

[11] Barussaud ML, Meurette G, Cassagnau E, et al. Mixed adenocarcinoma and squamous cell carcinoma arising in a gastric duplication cyst. Gastroenterol Clin Biol. 2008; 32: 188-191.

[12] Szabó J, Falkus B, Simon É, et al. Late gastrointestinal metastases of invasive lobular breast carcinoma mimicking Crohn's disease. [Crohn-betegséget utánzó késói gyomor-bél traktusi metasztázisokat adó invazív lobularis emlőcarcinoma.] Orv Hetil. 2010; 151: 1666-1671.

\author{
"Inter duos litigantes tertius gaudet." \\ (Ha ketten veszekednek, a harmadik örül.)
}

